\author{
MACIEJ OLCZYK \\ Uniwersytet im. Adama Mickiewicza w Poznaniu \\ Wydział Teologiczny
}

\title{
Nadzwyczajny Synod Biskupów na temat rodziny Anno Domini 2014. Między wolą Chrystusa i wiarą Kościoła a oczekiwaniami świata
}

The Extraordinary Synod of Bishops about the Family Anno Domini 2014.

Between the Will of Christ and the Faith of the Church and Expectations of the World

Nie ulega dziś najmniejszej wątpliwości, że małżeństwo i rodzina są instytucjami społecznymi, wymagającymi wielowymiarowego wsparcia i pomocy. Wyrazem troski Kościoła katolickiego w tym względzie był odbywający się w październiku 2014 roku Nadzwyczajny Synod Biskupów poświęcony rodzinie. Stanowił on etap przygotowawczy do zaplanowanego na rok 2015 synodu zwyczajnego. Od samego początku obrad synodu, a nawet jeszcze przed jego rozpoczęciem, towarzyszyła mu spora doza emocji i komentarzy medialnych. Niektóre z nich zaczęły kreować specyficzny klimat wokół synodu, upatrując w nim momentu przełomowego, który zmieni dotychczasową dyscyplinę, a może nawet i doktrynę Kościoła, dotyczącą małżeństwa i rodziny.

Warto zatem przeanalizować raz jeszcze to wszystko, co działo się wokół synodu oraz przypomnieć wnioski obrad synodalnych. Zaproponowana poniżej refleksja ukazuje napięcie, jakie ujawniło się podczas trwania synodu, napięcie uświadamiające różnicę pomiędzy strzeżoną i wypełnianą w Kościele wolą Chrystusa a współczesnymi oczekiwaniami świata.

\section{NADZWYCZAJNY SYNOD POŚWIĘCONY RODZINIE AD 2014}

Na samym początku naszej refleksji warto przypomnieć, na czym polega rola synodu biskupów w Kościele katolickim. Celem wyjaśnienia natury oraz zadań tej instytucji powinniśmy odwołać się do odnowionej nauki Soboru Watykańskiego II na temat Kościoła, a zwłaszcza do jego nauczania, dotyczącego łączności 
biskupów z papieżem. Sobór podkreślił wagę jedności Kościoła oraz kolegialności biskupów. Z kolei papież Jan Paweł II kładł wielki nacisk, aby dać tej jedności z biskupami konkretny wyraz, zwołując kilkakrotnie synody o różnej tematyce (o pojednaniu i pokucie, o Eucharystii, o formacji kapłańskiej, o życiu konsekrowanym, o zadaniach świeckich w kościele, o małżeństwie i rodzinie).

W roku 2015 minęło 50-lecie ustanowienia synodu biskupów. Jest to więc instytucja stosunkowo młoda. Ustanowił ją papież Paweł VI, na krótko przed zakończeniem soboru watykańskiego II w 1965 roku.

Synod nie jest organem ustawodawczym, lecz doradczym. Jego zadaniem jest wspierać Ojca Świętego. Zgodnie z Kodeksem prawa kanonicznego z 1983 r., „W wykonywaniu zadania Biskupowi Rzymskiemu świadczą pomoc biskupi, którzy mogą to czynić w różny sposób, w tym także poprzez synod biskupów"'. Nieco dalej kodeks wymienia trzy cele synodu:

1) „pobudzać ścisłą łączność między Biskupem Rzymu i biskupami”;

2) „świadczyć Biskupowi Rzymskiemu pomoc swoją radą w celu zachowania i wzrostu wiary oraz obyczajów, a także zachowania i umocnienia dyscypliny kościelnej";

3) „rozważać problemy związane z działalnością Kościoła w świecie”2.

Prawo kościelne reguluje kompetencje synodu, precyzując, że „zadaniem synodu biskupów jest rozpatrywanie przedstawionych mu spraw i wysuwanie wniosków, nie zaś ich rozstrzyganie i wydawanie dekretów, chyba że w pewnych wypadkach zostanie on wyposażony przez Biskupa Rzymskiego w głos decydujący, wówczas Biskup Rzymski ma prawo zatwierdzić decyzje synodu"3.

Zwołanie synodu należy do papieża, podobnie jak zatwierdzenie wyboru członków, ustalanie tematyki, jaka ma być rozpatrywana, zaplanowanie porządku obrad oraz ich zamknięcie 4 . Pomimo tego należy podkreślić, że synod działa kolegialnie i to - jak thumaczy kard. Zenon Grocholewski - do pewnego stopnia nawet $\mathrm{w}$ wymiarze uniwersalnym. Purpurat w następujący sposób wyjaśnia kolejne etapy przebiegu każdego synodu: „Najpierw w całym Kościele przeprowadza się konsultacje w sprawie przedmiotu obrad synodu. Po wybraniu tematu zostaje opracowany przez Sekretariat Synodu dokument wstępny, zawierający zarys problematyki (Lineamenta), który zostaje rozesłany do wszystkich episkopatów i innych zainteresowanych instytucji, z prośbą o uwagi i propozycje. $\mathrm{Na}$ podstawie otrzymanych odpowiedzi sporządza się dokument zwany Instrumentum laboris, który jest podstawą dyskusji zgromadzenia synodalnego. Zarówno Lineamenta, jak i Instrumentum laboris są publikowane, toteż biskupi uczestniczący w synodzie, oprócz własnych refleksji, mogą przedstawić zgromadzeniu

\footnotetext{
${ }^{1}$ KPK, kan. 334.

${ }^{2}$ KPK, kan. 342.

${ }^{3}$ KPK, kan. 343.

${ }^{4}$ Por. KPK, kan. 344.
} 
także doświadczenia i dezyderaty biskupów własnego kraju. Wysunięte w czasie zebrań postulaty są najpierw poddawane pod głosowanie uczestników synodu, a dopiero potem przedstawiane Ojcu Świętemu jako Propositiones" 5 .

Synod biskupów jest ciałem doradczym o szczególnym charakterze. Biora w nim bowiem udział biskupi z całego świata, a obrady i dyskusje synodu odzwierciedlają problemy, doświadczenia i propozycje całego Kościoła.

Odbywający się w październiku 2014 roku synod w Watykanie miał charakter nadzwyczajny. Nadzwyczajne sesje synodu powołuje się dla omówienia spraw pilnych, wymagających szybkiego rozwiązania. Synod może się też gromadzić na zgromadzeniu specjalnym, na którym rozpatrywane są sprawy dotyczące bezpośrednio jednego lub kilku regionów (np. kościoła w Afryce lub w Azji).

Tematem zasadniczym Nadzwyczajnego Synodu Biskupów w 2014 r. była rodzina. Hasło obrad brzmiało następująco: „Wyzwania duszpasterskie związane z rodziną w kontekście ewangelizacji”. Zgromadzenie trwało w Watykanie od 5 do 19 października. Wzięli w nim udział przewodniczący episkopatów, zwierzchnicy Kościołów wschodnich, szefowie kongregacji, a także m.in. uczestnicy wyznaczeni przez Papieża oraz niekatolicy. W sumie: 253 osoby, w tym również z Polski, m.in. przewodniczący Episkopatu abp Stanisław Gądecki, abp Zygmunt Zimowski oraz kardynałowie Zenon Grocholewski i Stanisław Ryłko.

Ważnym dla przebiegu obrad był dokument przygotowany przez Sekretariat Synodu, opublikowany we wrześniu, który powstał na bazie wcześniej rozesłanej po całym świecie tzw. ankiety Franciszka, wypełnianej przez wierzących w kościołach lokalnych. Papież chciał przez tą ankietę zorientować się, jak w poszczególnych częściach świata wygląda sytuacja rodziny, jakie są jej blaski, z jakimi problemami się boryka. Dokument nazywany fachowo Instrumentum laboris, wyznaczył porządek obrad oraz sugerował zagadnienia do omówienia. Zgodnie z przyjętą metodą pracy, kolejne sesje generalne (zebrania) miały swoją tematykę, odwołującą się do poszczególnych części tegoż dokumentu. Ojcowie synodalni wypowiadali się na konkretny temat, a ich przemówienie nie mogło trwać dłużej niż cztery minuty. Każde z zebrań generalnych rozpoczynało się świadectwem zaproszonych gości świeckich. Treść poszczególnych wystapień nie była podawana bezpośrednio do wiadomości publicznej, a z poruszaną tematyką zapoznawał dziennikarzy Rzecznik Stolicy Apostolskiej, jego asystenci oraz złożone z biskupów biuro prasowe. Każdy biskup mógł otwarcie komunikować mediom swoje stanowisko, co potwierdzało otwartość synodu na świat i dowodziło, iż Papież oraz synod chcą szczerze pochylić się nad problemami rodziny we współczesnym świecie i szukać pastoralnych rozwiązań, aby jej pomóc ${ }^{6}$.

\footnotetext{
${ }^{5}$ Z. Grocholewski, Synod Biskupów w życiu Kościoła, http://www.opoka.org.pl/biblioteka/W/ WR/inne/grocholewski_synodbp2005.html\# [dostęp: 3.11.2014].

${ }^{6}$ Por. Synod o rodzinie - tydzień pierwszy, http://ekai.pl/wydarzenia/temat_dnia/x82770/synodo-rodzinie-tydzien-pierwszy/?page $=5$ [dostęp: 12.10.2014].
} 
W tym miejscu warto poczynić pewną dygresję. Otóż w wielu mediach w Polsce podnoszono zarzut, zupełnie niesłuszny, że dokument Instrumentum laboris nie został przetłumaczony na język polski. Tymczasem dokumenty tego typu również na wcześniejszych synodach zasadniczo nie były tłumaczone na język polski. Nie są to bowiem dokumenty końcowe, zawierające treści wiążące wiernych i będące wykładnią rozumienia omawianych problemów. Instrumentum laboris jest swego rodzaju roboczym planem obrad i ukazuje się w językach, w których obraduje synod. Instrumentum nie jest dokumentem utrzymywanym w tajemnicy, ale - ze względu na jego roboczy charakter - nie wymaga thumaczenia czy publikacji we wszystkich językach świata. Ważniejszym jest dokument podsumowujący obrady synodu, tzw. Relatio Synodi, który możemy przeczytać w języku polskim. Należy jednak pamiętać, że jest to jedynie pewnego rodzaju sprawozdanie z przebiegu obrad, a nie dokument doktrynalny.

\section{OBRADY SYNODU A MEDIALNE SPEKULACJE I KONTROWERSJE}

Zanim Watykan opublikował wspomnianą relację z obrad synodalnych w postaci oficjalnego Relatio Synodi, za sprawą mediów docierały do nas różnego rodzaju informacje na temat przebiegu posiedzenia i treści toczących się obrad. Przekaz medialny nie zawsze rzetelnie informował o przebiegu prac synodu, zdarzało się, że stawał się on swoistym wyrazem oczekiwań świata, a może nawet w pewnym sensie środkiem nacisku na obradujących biskupów, aby wymóc na nich oczekiwane decyzje. Z większości przekazów medialnych można było odnieść wrażenie, że synod jest zwołany dla dwóch zasadniczych tematów: dopuszczenia rozwiedzionych, żyjących w powtórnych związkach cywilnych, do komunii świętej oraz zgody na małżeństwa homoseksualne (lub co najmniej akceptacji związków partnerskich osób tej samej płci). W takiej optyce większość mediów świeckich nie tylko relacjonowało obrady synodu, ale jeszcze przed jego rozpoczęciem próbowało określić, co należy uznać za najważniejszą problematykę synodu. Nie ulega wątpliwości, że wspomniane dwa problemy należą do kwestii ważnych i dyskutowanych podczas synodu, ale nie można ich uznać za tematy kluczowe czy priorytetowe. Synod był poświęcony rodzinie, miał pogłębić pozytywne jej rozumienie, szukać dróg dla duszpasterstwa umacniającego małżeństwo i rodzinę. Oczywiście nie mogło zabraknąć w obradach również miejsca na bolączki i trudności. Lecz nie one były zasadniczymi treściami obrad. Synod od nich nie uciekał, ale w przekazie medialnym fakt pochylenia się nad tymi bolączkami stał się pretekstem do wykreowania zupełnie nieprawdziwego obrazu synodu. W niewielkim stopniu relacjonowano pozytywne treści dotyczące małżeństwa i rodziny, za to dokładnie przytaczano wypowiedzi osób, wskazujących na problemy rozwiedzionych czy homoseksualistów. W ten sposób selektywny i filtrujący przekaz, docierający za sprawą większości laickich mediów, nie pomógł we właściwym odbiorze synodu. 
Na potwierdzenie warto przytoczyć dwie wypowiedzi, które, gorliwie cytowane w niektórych mediach, tworzyły wrażenie, jakoby synod, a może nawet papież Franciszek, dokonają rewolucyjnych zmian w nauczaniu Kościoła na wspomniane tematy, tzn. dopuszczą rozwiedzionych w powtórnych małżeństwach cywilnych do komunii św. i zaakceptują jakąś formę związków homoseksualnych.

Cytowany w polskich mediach włoski watykanista Giacomo Galeazzi z dziennika La Stampa w następujący sposób prorokował na temat zmian, jakie przyniesie lub chociaż zainicjuje synod: „W kwestiach dotyczących rodziny, od owej komunii począwszy, a na stosunku do antykoncepcji skończywszy, Kościół się otwiera. By być gotowym na wyzwania stojące przed Kościołem w kwestii duszpasterstwa rodzin, Kościół musi na nowo odkryć zalecenia II Soboru Watykańskiego dotyczące komunii. Zmienił się kierunek wiatru. Przewodniczący niemieckiego episkopatu Reinhard Max zebrał głosy tych biskupów, którzy są za komunią dla rozwodników, którzy ponownie zawarli małżeństwa (Maradiaga, Forte, Napier, Celli). Są i tacy, którzy wznoszą mury, jak kardynał Burke (wysoki urzędnik kurii rzymskiej - przyp. red.), który głośno mówi, że «myślenie, iż synod może zmienić nauczanie Kościoła, jest nierealistyczne»"”.

Zobaczmy, jak tendencyjnie formułuje swoją wypowiedź przywołany włoski dziennikarz: próba wymuszenia zmian w nauce Kościoła jest nazwana „zmianą kierunku wiatru", z powołaniem się na kilku tzw. postępowych hierarchów, zaś obrońca doktryny ewangelicznej nazwany zostaje tym, który „wznosi mury”, a redakcja odpowiedzialna za polskie thumaczenie dodaje, że ów kardynał, broniący tradycyjnej nauki Kościoła, jest „wysokim urzędnikiem kurii rzymskiej”, co pośrednio stygmatyzuje negatywnie w odbiorze jego stanowisko, jak i samą osobę (domyślnie: nieżyciowy urzędnik).

A oto drugi przykład. „Tygodnik Powszechny” relacjonuje, jak to uczestniczące w obradach synodu „państwo Pirola opowiedziało zgromadzonym historię swych znajomych, którzy jako praktykujący katolicy stanęli przed dylematem, czy powinni zapraszać na święta Bożego Narodzenia partnera ich syna - geja. Ci ludzie całkowicie akceptują nauczanie Kościoła w kwestii homoseksualizmu i byli też świadomi, że ich wnuki zobaczą w ich domu syna z partnerem. Mimo to zdecydowali się na to zaproszenie. «To nasz syn» - tłumaczyli. Australijscy małżonkowie nie tylko pochwalili znajomych za ten akt, ale ojcom synodalnym dali ich też za przykład do naśladowania w życiu parafialnym. I zaznaczyli, że właśnie za takimi przykładami chrześcijańskiego postępowania winna iść współczesna ewangelizacja oraz nauczanie Kościoła, którego główną misją jest pokazywanie światu Bożej miłości.

${ }^{7}$ A.J. Dudek, Giacomo Galeazzi: Za Franciszka rewolucja formy staje się rewolucja treści. Synod jest tego dowodem, http://natemat.pl/120293, giacomo-galeazzi-za-franciszka-rewolucja-for my-staje-sie-rewolucja-tresci-synod-jest-tego-dowodem [dostęp: 3.11.2014]. 
Naturalnie temat ten powrócił w komentarzach. Powrócił też na konferencji prasowej, w której uczestniczył abp Ignatius Kaigama z Nigerii. Dziennikarze zapytali go o prawo niedawno wprowadzone w tym kraju, które penalizuje związki homoseksualne oraz o wsparcie tamtejszego Kościoła dla tego rozwiązania. Duchowny musiał się gęsto tłumaczyć. Wyjaśnił, że, owszem, biskupi wsparli ten projekt, ale tylko w tym sensie, że chcieli bronić tradycyjnego afrykańskiego rozumienia małżeństwa jako związku kobiety i mężczyzny. Natomiast nigdy nie pochwalali karania za orientację. «Nasz Kościół jest na pierwszej linii walki w obronie każdej osoby, także o orientacji homoseksualnej, która jest nękana i więziona» - mówił metropolita miasta Dżos (ang. Jos)"

Wobec takiego przekazu niektórych mediów można zacząć żywić pewne wątpliwości co do nauki Kościoła albo co najmniej do tego, co naprawdę działo się na synodzie w Rzymie. Czy Kościół w ważnych kwestiach doktrynalnych jest podzielony? Czy może istnieją dwa kościoły: postępowego papieża Franciszka i grupy reformatorów, a po drugiej stronie konserwatywnych biskupów, zamkniętych na głos zmieniającego się świata, tak jak np. polski abp S. Gądecki, powołujący się na Ewangelię i tradycyjne nauczanie Kościoła, wyraźnie sformułowane przez św. papieża Jana Pawła II? Komu może zależeć na budowaniu takich opozycji i medialnym dzieleniu Kościoła? Można przypuszczać, że są to ludzie żywo zainteresowani osłabieniem jego autorytetu, a zwłaszcza sianiem zamętu w kwestiach nauczania moralnego, z którym sami się nie zgadzają.

Dla pełnego obrazu genezy kontrowersji, jakie pojawiły się wokół obrad synodalnych, należy dodać również zamieszanie wywołane relacją przygotowaną przez sekretariat synodu z przebiegu pierwszego tygodnia obrad. Relatio post disceptationem sprawiało wrażenie dokumentu mocno wychylonego $\mathrm{w}$ stronę rozwiązań liberalnych, czego przejawem było np. wątpliwe rozumienie prawa stopniowości, które zakładałoby uznanie konkubinatów jako etapu na drodze do doskonałości. Podobne wątpliwości budziło zbyt daleko idące twierdzenie, dotyczące związków homoseksualnych, sugerujące możliwość zgody na adopcję dzieci przez takie pary. Wreszcie idea komunii duchowej czy możliwość przyjmowania Eucharystii przez osoby rozwiedzione, trwające w powtórnych związkach cywilnych, wydawały się nie do pogodzenia z dotychczasową nauką Kościoła. Zdaniem kard. Raymonda Burke'a, Sekretariat Synodu sprawiał wrażenie, jakby faworyzował poglądy liberalne, których jednak nie akceptuje wielu ojców synodalnych?.

Być może wynikało to stąd, że pierwsza część synodu skupiła się na opisie aktualnej rzeczywistości społeczno-kulturowej, w jakiej przychodzi żyć współ-

\footnotetext{
${ }^{8}$ Seks, gender i homo, czyli co stychać na Synodzie, http://tygodnik.onet.pl/wwwylacznie/seksgender-i-homo-czyli-co-slychac-na-synodzie/1xnjg [dostęp: 3.11.2014].

${ }^{9}$ Synod - duszpasterskie trzęsienie ziemi, http://ekai.pl/wydarzenia/temat_dnia/x82880/synodduszpasterskie-trzesienie-ziemi/?page $=4$, [dostęp: 12.11.2014].
} 
czesnym rodzinom i realia te w znacznej mierze wpłynęły na ton zredagowanego dokumentu. Przypomnijmy jednak, że charakter omawianego sprawozdania był czysto referujący, a nie doktrynalny, jednak w odbiorze medialnym mogło powstać wrażenie (zwłaszcza wówczas, gdy media nie informowały rzetelnie o charakterze przywoływanego dokumentu), że Kościół podąża w stronę epokowych zmian w nauczaniu.

\section{ZAMIESZANIE WOKÓŁ RELATIO POST DISCEPTATIONEM}

Niestety, trzeba również przyznać, że wspomniany dokument Relatio post disceptationem, oprócz tego, że został niewłaściwie odczytany i zinterpretowany w przekazach medialnych, zawierał sam w sobie wiele sformułowań niedopracowanych i nie do zaakceptowania przez ojców synodalnych. Wspomniany powyżej kard. Raymond Burke ocenia go bardzo surowo: „Dokument ten pozbawiony jest solidnych podstaw w Piśmie Świętym i Magisterium. W sprawie, w której Kościół ma bardzo bogate i jasne nauczanie, daje wrażenie wymyślenia czegoś zupełnie nowego"10. Z kolei abp Stanisław Gądecki ubolewał nad ostatecznym wydźwiękiem sprawozdania, które jawi się jako zgoda na zwycięstwo „poglądu światowego", że grzech zastapiono niedoskonałością, „która prowadzi do doskonałości”. W konsekwencji, ,zamiast być zachętą do wierności wartości rodziny, wydaje się akceptować wszystko, tak jak jest. Powstaje też wrażenie, że dotąd nauczanie Kościoła było niemiłosierne, podczas gdy teraz zacznie się nauczanie miłosierne"11.

Wróćmy jednak do obrad synodu. Wydaje się, że pojawienie się różnych opinii i głosów podczas debaty nie jest niczym gorszącym. Przecież synod miał podjąć refleksję na temat rzeczywistych blasków i cieni współczesnej rodziny. Sam Papież zachęcał w przemówieniu wprowadzającym, aby szczerze mówić o blaskach i cieniach współczesnej rodziny. Zapraszał do otwartości: „Niech nikt nie mówi: «Tego nie można powiedzieć; ktoś o mnie pomyśli tak czy inaczej». Trzeba powiedzieć to wszystko, co czujemy, szczerze i otwarcie"12. Zachęta Papieża wydaje się bardzo słuszna, nie wszyscy jednak pamiętali, że „to, co się czuje”, a nawet „współczuje”, nie powinno wpływać na obniżanie ewangelicznych wymagań sformułowanych przez Chrystusa i obecnych w Piśmie Świętym. $\mathrm{W}$ przeciwnym razie zaoferuje się wiernym - zamiast autentycznej pomocy wy-

${ }^{10}$ Synod - duszpasterskie trzęsienie ziemi, w: http://ekai.pl/wydarzenia/temat_dnia/x82880/ synod-duszpasterskie-trzesienie-ziemi/?page=4, [dostęp: 12.11.2014].

${ }^{11}$ Synod-duszpasterskie trzęsienie ziemi, http://ekai.pl/wydarzenia/temat_dnia/x82880/synodduszpasterskie-trzesienie-ziemi/?page $=4$ [dostęp: 12.11.2014].

${ }^{12}$ Papież do ojców synodalnych: mówcie szczerze i pokornie stuchajcie, http://ekai.pl/wyda rzenia/temat_dnia/x82577/papiez-do-ojcow-synodalnych-mowcie-szczerze-i-pokornie-sluchajcie/ [dostęp: 11.10.2014]. 
zwalającej i uzdrawiającej mocy Bożego Słowa - spreparowany pod dyktando świata produkt „ewangelio-podobny”. Przestrzegał przed tym ryzykiem arcybiskup Rygi Zbigniew Stankiewicz, nazywając takie postępowanie „tańczeniem pod muzyczkę świata”. Tłumaczył, że „przeważająca większość biskupów myśli zdrowo i nie zamierza popuścić i poddać się temu naciskowi. Aczkolwiek ci, którzy jakoś się temu poddają, czynią to, jak myślę, w dobrej wierze, chcą wyjść naprzeciw tym, którzy doświadczają trudności. W moim przemówieniu podkreśliłem jednak, że poddając się naciskowi świata i tracąc własną tożsamość, na dłuższą metę stracimy. Bo światu tak naprawdę nie jest potrzebna podróbka Ewangelii, ale jest potrzebne światło, prawda Ewangelii. I to przekonuje ludzi, bo Ewangelia ma moc. Jeżeli nie zniekształcamy jej przesłania, to ono dociera do sumień i umysłów ludzi, przekonuje ich i pociąga. A jeżeli to będzie coś rozwodnionego, to, niestety, najpierw będą nam klaskać, a potem nikomu to nie będzie potrzebne, tylko wieprzom na podeptanie. Mam nadzieję, że w grupach językowych będzie na ten temat dyskusja i że przemówienia korygujące ten dokument zrobią swoje i coś się zmieni"13.

Obecność wątków kontrowersyjnych w dyskusjach jest dowodem na otwartość biskupów i Papieża, dowodem na to, że nikomu nie „kneblowano ust”, nie cenzurowano wypowiedzi. Ten autentyzm został jednak opacznie wykorzystany przez ludzi naciskających na Kościół, aby zmienił swe nauczanie i porzucił wierność Ewangelii. Stąd wiele niepotrzebnego zamętu i dezorientacji. Dziś trzeba na nowo tłumaczyć, że czym innym jest opis rzeczywistości czy nawet osobiste opinie hierarchów, pojawiające się podczas synodu, a zdecydowanie czym innym depozyt wiary, zbudowany na fundamencie prawd objawionych, dotyczących natury człowieka, powołania mężczyzny i kobiety, sensu małżeństwa i rodziny. W tych kwestiach treści objawione są jednoznaczne i nie dopuszczają zmian ze względu na panujące obyczaje. Gdyby tak nie było, to rozwiązła obyczajowość starożytnego świata już u początków chrześcijaństwa wpłynęłaby skutecznie na złagodzenie wymagań zapisanych w Piśmie Świętym na temat nierozerwalności małżeństwa czy niegodziwości stosunków homoseksualnych. Tak się jednak nie stało. Dlaczego? Ponieważ chrześcijanie wiedzieli i wiedzą, że dla wierzących bardziej wiarygodne i wiążące jest niezmienne słowo Boga, aniżeli ludzkie naciski. „Trzeba bardziej słuchać Boga, niż ludzi” (Dz 5,29).

W odniesieniu do zaistniałych kontrowersji, powstałych czy to na skutek niedopracowanych stwierdzen, zawartych $\mathrm{w}$ sprawozdaniu z pierwszego tygodnia, czy spowodowanych nierzetelną polityką informacyjną niektórych mediów (czy nawet w pewnym stopniu przez media wykreowanych), kard. Gerhard Müller, prefekt Kongregacji Doktryny Wiary (notabene pochodzący również z postępo-

${ }^{13}$ Synod - duszpasterskie trzęsienie ziemi, http://ekai.pl/wydarzenia/temat_dnia/x82880/synodduszpasterskie-trzesienie-ziemi/?page $=4$ [dostęp: 12.11.2014]. 
wych Niemiec), w jednym z wywiadów wyraził się następująco: „Jest wiele mediów, ale jest tylko jeden Mediator, czyli Jezus Chrystus i Jego Ewangelia. W związku z tym Słowo Boże nie może być nigdy w jakiś sposób pominięte i nie może zostać naruszone w jakimkolwiek swoim fragmencie. Musi być w całości przyjęte. Kościół ani przed, ani w czasie, ani po synodzie nie może zmienić tego, co wypływa z nauczania Chrystusa. W odniesieniu do małżeństwa określają to przede wszystkim słowa: «Co Bóg złączył, człowiek niech nie rozdziela». Synod został zwołany przez papieża Franciszka, aby wzmocnić rodzinę opartą na nierozerwalnym małżeństwie, a nie po to, aby ją osłabić. Chcemy lepiej pomóc jej duszpastersko. To był cel obrad, a nie zmiana doktryny"14.

W odniesieniu natomiast do wypowiedzi niektórych biskupów, sugerujących istnienie cienia możliwości zmian ewangelicznej doktryny Kościoła, ten sam kardynał stwierdził ze smutkiem: „Niestety, są przedstawiciele Kościoła, a nawet biskupi, którzy dali się w jakiś sposób oślepić, na których zlaicyzowane społeczeństwo tak wpłynęło, że odciągnęło ich od tego głównego tematu czy od nauki Kościoła opartej na objawieniu. Zaczęli się zastanawiać nad różnymi możliwościami, czy to albo to byłoby możliwe, zapominając o fundamencie... Być może proponowanie pewnych wątpliwych rozwiązań jest kwestią ich zaangażowania w trudne sytuacje, w jakich znaleźli się ludzie, być może kieruje nimi chęć pomocy drugiemu człowiekowi... Wszystko to szlachetne, ale trzeba zawsze pamiętać, że jest jedna „agenda”, którą mamy, agenda Kościoła, która opiera się na przekazanym objawieniu Boga w Jezusie Chrystusie. A to jest właściwie wszystko, co mamy najważniejszego, gdy to się gubi, gubi się także inne aspekty"15.

\section{PRZESŁANIE SYNODU W ŚWIETLE DOKUMENTU ZAMYKAJĄCEGO OBRADY}

Na zakończenie nadzwyczajnego synodu ukazał się dokument podsumowujący obrady, tzw. Relatio Synodi. Na początek oddajmy głos mediom, komentującym fakt publikacji tego dokumentu. Konrad Sawicki, publicysta i redaktor „Więzi”, pisze w krótkim komentarzu internetowym pod auspicjami „Tygodnika Powszechnego":

„Relatio finalis głosowano fragment po fragmencie. Na 62 paragrafy 3 nie uzyskały wymaganych $2 / 3$ głosów. Pierwszy dotyczy ,przyjęcia osób homoseksualnych" (118 za i 62 przeciw), a pozostałe dwa - osób rozwiedzionych i żyjących w ponownych związkach cywilnych, w tym kwestii dopuszczenia ich do sakramentów oraz tzw. komunii duchowej (104 i 112 za oraz 74 i 64 przeciw).

\footnotetext{
${ }^{14}$ S. Jagodziński, G. Müller, Niektórzy biskupi dali się oślepić, http://www.naszdziennik.pl/ wiara-kosciol-na-swiecie/106377,niektorzy-biskupi-dali-sie-oslepic.html [dostęp: 3.11.2014].

${ }^{15}$ S. Jagodziński, G. Müller, Niektórzy biskupi dali się oślepić, http://www.naszdziennik.pl/ wiara-kosciol-na-swiecie/106377, niektorzy-biskupi-dali-sie-oslepic.html [dostęp: 3.11.2014].
} 
Mimo że te fragmenty nie uzyskały odpowiedniego wsparcia ojców synodalnych, Franciszek zadecydował, że zostaną one opublikowane razem z innymi, co jest kompletnym zaskoczeniem. Co więcej, do publicznej wiadomości zostanie podany rozkład głosów dotyczący każdego paragrafu. Tak, by było jasne, jak dużym poparciem cieszył się dany temat sprawozdania.

Warte podkreślenia są dwie sprawy. Po pierwsze to, że najbardziej kontrowersyjne passusy - mimo że nieprzyjęte - i tak uzyskały grubo ponad połowę głosów. A to z kolei oznacza, i to jest druga uwaga, iż istnieje wola biskupów Kościoła katolickiego, by na te tematy dalej dyskutować. Prawdopodobnie $\mathrm{z}$ tego powodu Papież zdecydował się na opublikowanie owych paragrafów mimo wszystko".

Autor powyższego tekstu nie wspomina, że problematyczne trzy punkty znajdują się w trzeciej części dokumentu, mówiącego o perspektywach duszpasterskich, a nie o depozycie prawd wiary. Należy uwzględnić tę różnicę, gdyż najbardziej doktrynalną częścią dokumentu jest część druga - i w niej zachowano w niezmienny sposób tradycyjne treści nauczania o małżeństwie i rodzinie. $\mathrm{Z}$ tego względu ta część - zupełnie przemilczana w mediach - jest fundamentem i punktem wyjścia dla poszukiwań duszpasterskich. Kto nie uznaje katolickich prawd wiary, ma problem ze zrozumieniem zasad chrześcijańskiego życia oraz pryncypiów oceny moralnej kontrowersyjnych postaw.

Przytoczona wypowiedź medialna przekonuje nas, że dla wyrobienia sobie pełnego obrazu przebiegu prac synodalnych, koniecznym jest zapoznanie się $\mathrm{z}$ całym dokumentem końcowym. Relatio Synodi składa się z trzech części, przy których warto się zatrzymać, aby mieć ogląd, czy zapowiadane przez media „rewolucyjne zmiany" w kwestiach małżeństwa i rodziny znalazły swe odzwierciedlenie w oficjalnym dokumencie watykańskim.

\section{CZĘŚĆ I. Słuchanie: kontekst i wyzwania związane z rodziną}

W pierwszej części dokument kreśli panoramę sytuacji współczesnych rodzin z jej blaskami i cieniami. Zwraca się uwagę na wartość relacji rodzinnych, odniesień międzypokoleniowych w zakresie wzajemnej pomocy i wsparcia. Pośród zjawisk pozytywnych wymienia się większą swobodę wypowiedzi i „lepsze uznanie praw kobiet i dzieci, przynajmniej w niektórych regionach" ${ }^{16}$. Ale, niestety, są też zjawiska niepokojące, takie jak wybujały indywidualizm, wynaturzający więzi rodzinne, samotność będąca gorzkim owocem braku Boga w życiu ludzi, ubóstwo i brak pewnej pracy, systemy podatkowe niekorzystne dla rodzin,

${ }^{16}$ Relatio Synodi (dalej: RS), nr 5. Dokument cytuję zgodnie z oficjalnym tłumaczeniem w j. polskim za: Relatio Synodi III Nadzwyczajnego Zgromadzenia Ogólnego (5-19 października 2014), http://archidiecezja.warszawa.pl/ksieza/dokumenty/stolica-apostolska/relatio-synodi/ [dostęp: 18.11.2015]. 
niewystarczające wsparcie rodziny ze strony instytucji społecznych i państwowych. Obserwuje się narastający kryzys demograficzny, trudności w przyjęciu narodzin dziecka, deficyt godnego traktowania starszych. Mnożą się zaburzenia emocjonalne oraz ujawnia się przemoc. Do tych problemów, występujących dość powszechnie, można dołączyć kwestie bardziej szczegółowe, takie jak poligamia czy tzw. małżeństwa na etapy, relatywizm lub indyferentyzm religijny w rodzinach, współżycie seksualne przed ślubem, konkubinat bez zamiaru legalizacji związku, ustawodawstwo niektórych państw osłabiające rodzinę zbudowaną na trwałym małżeństwie mężczyzny i kobiety. Niestety, postępująca sekularyzacja sprawia, że wiara dla wielu ludzi przestaje być zjawiskiem społecznym, a coraz silniej lansuje się pogląd, że religia jest sprawą prywatną ${ }^{17}$. Wśród bolączek rodziny zauważyć należy również cierpienie dzieci dorastających tylko z jednym rodzicem, wzrastającą liczbę rozwodów, nikłą obecność ojców w procesie wychowawczym, nierówny podział obowiązków rodzinnych. Wciąż zagrożona jest godność kobiety, która jest poniżana i wykorzystywana, dar macierzyństwa bywa przedstawiany jako balast. Hańbiącym faktem jest seksualne wykorzystywanie dzieci, różne formy przemocy, terroryzm oraz przestępczość, będąca znakiem degradacji relacji rodzinnych.

Szczególnym obszarem zmian antropologiczno-kulturowych jest świat ludzkich emocji i uczuć. Docenienie tego wymiaru ludzkiej egzystencji jest bardzo ważne i może pomóc w lepszym budowaniu trwałych relacji. Od strony pozytywnej wpływa to na „większą potrzebę zajmowania się sobą, wewnętrznego poznania samych siebie, życia w większej zgodności $\mathrm{z}$ własnymi emocjami i uczuciami, budowania głębokich więzi uczuciowych; to słuszne dążenie może doprowadzić do otwarcia na pragnienie zaangażowania w tworzenie więzi opartych na wzajemnym obdarowaniu soba, kreatywnych, odpowiedzialnych i solidarnych, takich jak więzi rodzinne" ${ }^{18}$. Niebezpieczeństwo kryje się w indywidualizmie oraz w egoizmie, nacechowanych „uczuciowością bez granic”, prowadzącą do niestabilności emocjonalnej. To negatywne zjawisko wyraża się w ,uczuciowości narcystycznej, niestałej i zmiennej, która nie pomaga osobom w osiagnnięciu większej dojrzałości. Niepokój budzi pewne rozpowszechnienie pornografii i komercjalizacji ciała, którym sprzyja również niewłaściwe posługiwanie się internetem. Należy też informować o sytuacji osób zmuszanych do uprawiania prostytucji. W tym kontekście pary są niekiedy niepewne, niezdecydowane i trudno im jest znajdować drogi rozwoju. Wiele osób ma tendencję do zatrzymywania się na pierwszych stadiach życia uczuciowego i seksualnego. Kryzys pary małżeńskiej destabilizuje rodzinę, a poprzez separacje i rozwody może mieć poważne konsekwencje w życiu dorosłych, dzieci i społeczeństwa, osłabiając jednost-

\footnotetext{
${ }^{17}$ Por. RS, nr 7.

${ }^{18} \mathrm{RS}, \mathrm{nr} 9$.
} 
kę i więzi społeczne.”19. W konsekwencji budzi się lęk przed trwałymi związkami, zobowiązaniami, a także coraz silniej zaznacza się mentalność antynatalistyczna.

W obliczu tak zarysowanych problemów współczesnej rodziny, a właściwie problemów współczesnych ludzi, czyli konkretnych osób tworzących relacje, małżeństwa i rodziny, Kościół nie chce pozostawać obojętny. Jak mówi dokument synodalny, „Kościół dostrzega potrzebę, aby powiedzieć słowo prawdy i nadziei" ${ }^{20}$, proponując współczesnemu światu rozważenie wspomnianych blasków i cieni rodziny w świetle Bożej mądrości i miłości.

\section{CZĘŚĆ II. Spojrzenie utkwione w Chrystusie: Ewangelia rodziny}

W drugiej części, którą uznać można za część doktrynalną dokumentu synodalnego, znajdujemy syntetyczny wykład podstawowych prawd wiary, dotyczących małżeństwa i rodziny. Ojcowie synodalni rozpoczynają tę cześć od spojrzenia na Jezusa $i$ na Jego nauczanie na temat małżeństwa i rodziny oraz na stosunek, jaki Jezus miał do ludzi doświadczających trudności w przestrzeni życia małżeńskiego. Nauczanie Jezusa ,potwierdza nierozerwalną jedność mężczyzny i kobiety, choć mówi, że «przez wzgląd na zatwardziałość serc waszych pozwolił wam Mojżesz oddalać wasze żony, lecz od początku tak nie było» (Mt 19,8). Nierozerwalności małżeństwa («Co więc Bóg złączył, niech człowiek nie rozdziela», Mt 19,6) nie należy przede wszystkim pojmować jako «brzemienia» narzuconego ludziom, lecz winna być postrzegana jako «dar» dla osób, które zawarły związek małżeński”21. Przychylność Jezusa wobec rodziny objawiła się m.in. w fakcie, że „przyjął rodzinę, zapoczątkował cuda na godach weselnych w Kanie, głosił przesłanie dotyczące znaczenia małżeństwa jako pełni objawienia, które przywraca początkowy zamysł Boga (Mt 19,3)"22. Pochylał się także nad osobami przeżywającymi trudności: rozmawiał z Samarytanką, prowadząc ją do poznania prawdy i nawrócenia (por. J 4,1-30), przebaczył grzech cudzołożnicy (por. J 8,1-11), okazując miłosierdzie grzesznikowi, ale nie pomniejszając wymagań moralnych („Idź i nie grzesz więcej”) ${ }^{23}$.

Omawiany dokument synodalny odwołuje się do katolickiej teologii małżeństwa i rodziny, powołując się na Boże objawienie, z którego odczytać możemy trzy etapy ujawniania się prawdy o małżeństwie i rodzinie. Księga Rodzaju ukazuje nam „rodzinę źródeł”, czyli ustanowione przez Boga małżeństwo Adama i Ewy (etap I). „Bóg nie tylko stworzył człowieka mężczyzną i kobietą (por. Rdz

\footnotetext{
${ }^{19} \mathrm{RS}, \mathrm{nr} 10$.

${ }^{20} \mathrm{RS}, \mathrm{nr} 11$.

${ }^{21} \mathrm{RS}, \mathrm{nr} 14$

${ }^{22} \mathrm{RS}, \mathrm{nr} 14$.

${ }^{23}$ Por. RS, nr 14.
} 
1,27), lecz ich także pobłogosławił, by byli płodni i się rozmnażali (por. Rdz 1,28). Dlatego «mężczyzna opuszcza ojca swego i matkę swoją i łączy się ze swą żoną tak ściśle, że stają się jednym ciałem» (Rdz 2,24)"24. Ta pierwotna komunia i małżeńska miłość pierwszych rodziców została zniszczona przez grzech i w dzieje ludzkości wdarła się przemoc, dominacja, pożądliwość, cierpienie mające wpływ na historyczne oblicze małżeństwa (etap II). Słabość ludzi i zatwardziałość ich serc skłoniła Mojżesza do uznania możliwości rozwodu (por. Pwt 24,1 i nast.). Człowiek grzeszny z wielkim trudem jest w stanie zbudować trwałe więzi, zaufać bezgranicznie drugiemu, kochać bezwarunkowo. Tęskni za autentyczną miłością, co może być odczytane jako znak przypomnienia o jego powołaniu do miłości i nostalgii za utraconym pierwotnym szczęściem wspólnoty z Bogiem i z innymi ludźmi. Dopiero zbawcza interwencja Chrystusa czyni na nowo możliwym przeżywanie miłości i jedności zgodnie z pierwotnym zamysłem Boga (etap III). Jak stwierdza synod, „Jezus, który pojednał w sobie wszystkie rzeczy, przywrócił małżeństwu i rodzinie ich pierwotną formę (por. Mk 10,1-12). Rodzina i małżeństwo zostały odkupione przez Chrystusa (por. Ef 5,21-32), odnowione na obraz Trójcy Przenajświętszej, tajemnicy, z której wypływa każda prawdziwa miłość. Przymierze małżeńskie, zapoczątkowane w dziele stworzenia i objawione w historii zbawienia, zyskuje pełne objawienie swego znaczenia w Chrystusie i w Jego Kościele. Od Chrystusa, za pośrednictwem Kościoła, małżeństwo i rodzina otrzymują potrzebną łaskę, by dać świadectwo miłości Boga i żyć życiem komunii” ${ }^{25}$.

Dokument synodu potwierdza, że Kościół wierny Bożemu objawieniu stara się odczytać z wydarzeń zbawczych zarówno prawdę o wielkim obdarowaniu, jakiego dostępuje odkupiony człowiek (a przez niego i relacja małżeńska), jak i wypływające $z$ tego obdarowania zobowiązania moralne.

Małżeństwo jest więc wspólnotą życia i miłości, a ponieważ odzyskuje swoją moc i pierwotne znaczenie przez sakramentalne uświęcenie, przemienia też miłość ludzką, przydając jej walorów nadprzyrodzonej miłości Boga. Miłość małżonków chrześcijańskich czerpie z miłości, jaką Chrystus umiłował Kościół i tym sposobem małżeństwo sakramentalne jest znakiem Chrystusowego oddania Kościołowi. Jest to oddanie nierozerwalne i wieczne, wyłączne i wierne, stąd też małżonkowie są dysponowani do przeżywania swojej relacji miłości na wzór miłości Chrystusa do Kościoła. Przywołując nauczanie Soboru Watykańskiego II, synod przypomina, że „«prawdziwa miłość między mężem a żoną» (Gaudium et spes, 49) pociaga za sobą wzajemny dar z siebie, zawiera i włącza wymiar seksualny i uczuciowy, odpowiadając planowi Bożemu (por. Gaudium et spes, 48-49). Ponadto Gaudium et spes 48 podkreśla zakorzenienie małżonków w Chrystusie:

\footnotetext{
${ }^{24} \mathrm{RS}, \mathrm{nr} 15$.

${ }^{25} \mathrm{RS}, \mathrm{nr} 16$.
} 
Chrystus Pan «przez sakrament małżeństwa wychodzi na spotkanie chrześcijańskim małżonkom» i pozostaje z nimi. We wcieleniu przyjmuje miłość ludzka, oczyszcza ja, doprowadza do pełni i obdarowuje małżonków, wraz ze swoim Duchem, zdolnością przeżywania jej, przenikając całe ich życie wiara, nadzieją i miłościa" 26 .

Zwrócenie w tym kontekście uwagi na pomoc Chrystusa jest niezwykle istotne. Sakramentalne małżeństwo nie jest nakładane przez Kościół na wierzących jako ciężar albo instytucja krepująca wolność jednostek. Sakrament małżeństwa jest darem doskonalącym ludzką miłość, włączającym tę miłość w nadprzyrodzoną miłość Boga, jest jakby przyłączeniem rzeki do wiecznego źródła, aby nigdy rzeka ta nie wyschła, aby nigdy nie zabrakło w niej życia, energii i świeżości. Dlatego też ,we wzajemnej akceptacji i z laską Chrystusa, zawierający związek małżeński ślubują sobie całkowity dar, wierność i otwarcie na życie, uznają, że podstawowymi elementami małżeństwa są dary, które otrzymują od Boga, traktując poważnie swoje wzajemne zobowiązanie w Jego imię i w obliczu Kościoła. A zatem, w wierze można przyjąć dobra małżeństwa jako zobowiązania, którym lepiej sprostać dzięki pomocy łaski sakramentu. Bóg uświęca miłość małżonków i potwierdza nierozerwalność związku, ofiarowując im pomoc, by żyli wiernie, wzajemnie się uzupełniając, i byli otwarci na życie"27.

Synod uznał również, że Kościół, kreśląc wobec wiernych ten wzniosły obraz miłości realizującej się w sakramentalnym małżeństwie, jest świadomy ludzkich ułomności i trudności, jakie mogą napotkać osoby wypełniające Boży zamysł względem małżeństwa i rodziny. Dlatego, naśladując samego Chrystusa, wyznaje, że „nie pomniejszając wartości ewangelicznego ideału, należy z miłosierdziem i cierpliwością towarzyszyć możliwym etapom rozwoju osób formujących się dzień po dniu. [...] Mały krok, pośród wielkich ludzkich ograniczeń, może bardziej podobać się Bogu niż poprawne na zewnątrz życie człowieka, spędzającego dni bez stawiania czoła poważnym trudnościom. Do wszystkich powinna dotrzeć pociecha oraz impuls zbawczej miłości Boga, działającej tajemniczo w każdym człowieku, niezależnie od jego ułomności i upadków» (Evangelii gaudium, 44)"28.

W tym też duchu synod z miłością i troską odnosi się do osób żyjących w związkach niesakramentalnych. Osoby te nie są wykluczone z Kościoła, wręcz przeciwnie, ich sytuacja czyni ich w specjalny sposób adresatami pasterskiej troski wspólnoty wierzących. Wobec osób, „które zawarły małżeństwo cywilne, osób rozwiedzionych, które zawarły ponowne związki, albo które po prostu żyją w konkubinacie, zadaniem Kościoła jest ukazywanie im Bożej pedagogii łaski

\footnotetext{
${ }^{26} \mathrm{RS}, \mathrm{nr} 17$.

${ }^{27} \mathrm{RS}, \mathrm{nr} 21$.

${ }^{28} \mathrm{RS}, \mathrm{nr} 24$.
} 
w ich życiu i pomaganie w osiagnięciu pełnej realizacji w nich Bożego planu. Kierując się spojrzeniem Chrystusa, którego światłość oświeca każdego człowieka (por. J 1,9; Gaudium et spes, 22), Kościół z miłością zwraca się ku tym, którzy uczestniczą w jego życiu w sposób niepełny, uznając, że łaska Boża działa także w ich życiu, dając im odwagę do pełnienia dobra, do troszczenia się z miłością jedno o drugie i służenia wspólnocie, w której żyją i pracują"29.

$\mathrm{Z}$ duszpasterskiego punktu widzenia, ważnym zadaniem dla Kościoła jest towarzyszenie nie tylko rodzinom stabilnym i sakramentalnym małżeństwom, aby dodawać im siły i wspierać je wobec niełatwych wyzwań, ale również otaczanie troską tych, którzy w różnym stopniu związani ze sobą (konkubinaty, powtórne małżeństwa cywilne), mogliby w przyszłości zawrzeć małżeństwo sakramentalne. Ojcowie synodalni wyjaśnili, jak w tym kontekście należałoby rozumieć miłosierdzie, do którego często odwoływano się podczas minionych obrad. Ich zdaniem, Kościół, „zgodnie z miłosiernym spojrzeniem Jezusa, powinien uważnie i z troską towarzyszyć swoim najsłabszym dzieciom, które doświadczyły miłości zranionej i zagubionej, przywracając im ufność i nadzieję, niczym światło latarni portowej lub pochodni wnoszonej pośród ludzi, aby oświecić tych, którzy zagubili kierunek lub znajdują się pośród zawieruchy. Świadomi, że największym miłosierdziem jest mówienie prawdy z miłością, wyjdźmy poza współczucie. Miłość miłosierna, podobnie jak przyciaga i jednoczy, tak przemienia i wywyższa. Zachęca do nawrócenia. I tak w ten sposób rozumiemy postawę Pana, który nie potępia cudzołożnej kobiety, lecz prosi, aby więcej nie grzeszyła (por. J 8,1-11)" ${ }^{30}$.

\section{CZĘŚĆ III. Konfrontacja - perspektywy duszpasterskie}

Ostatnia część Relatio Synodi to próba nakreślenia praktycznych kierunków działań duszpasterskich dla dobra współczesnej rodziny. Wskazano zatem, już na samym początku tej części, kilka zasad generalnych, jakie powinny być uwzględnione w posłudze duszpasterskiej. Można wśród nich wymienić następujące:

a) Ewangelizacja jest obowiązkiem nie tylko duchownych, ale całego Ludu Bożego, a w tym szczególnym wymiarze, o którym mowa, ważna rola przypada samym małżonkom i rodzinom;

b) Pamiętać należy o prymacie łaski Bożej, działającej w sercach wierzących i dodającej mocy w ludzkiej słabości. „Ewangelia rodziny jest radością, która «napełnia serce i całe życie», bowiem w Chrystusie zostaliśmy «wyzwoleni od grzechu, od smutku, od wewnętrznej pustki, od izolacji» (Evangelii gaudium, 1). W świetle przypowieści o siewcy (por. Mt 13,3),

\footnotetext{
${ }^{29} \mathrm{RS}, \mathrm{nr} 25$.

${ }^{30} \mathrm{RS}, \mathrm{nr} 28$.
} 
naszym zadaniem jest współpracowanie w zasiewie - reszta jest dziełem Boga. Nie należy też zapominać, że Kościół, który głosi naukę o rodzinie, jest znakiem sprzeciwu"31;

c) Całemu Kościołowi potrzebne jest „,nawrócenie misyjne”, polegające na zaangażowanym i żywym głoszeniu Chrystusa, które jest w stanie wzbudzać wiarę tam, gdzie ona przygasła, pamiętając, że do kryzysu małżeństwa rodziny w dużej mierze przyczynił się kryzys wiary, co z kolei przerwało naturalny proces jej przekazywania wśród najbliższych w środowisku domowym;

d) W przepowiadaniu potrzeba zmiany języka, aby prowadził on do doświadczenia, że „Ewangelia rodziny jest odpowiedzią na najgłębsze oczekiwania człowieka - jego godność i jego pełną realizację we wzajemnym darze, w jedności i w płodności. Nie chodzi jedynie o przedstawianie norm, ale o ukazywanie wartości w odpowiedzi na zapotrzebowanie na nie, jakie dziś obserwuje się także w krajach najbardziej zlaicyzowanych"'32;

e) Należy zadbać o duchową formację małżonków w oparciu o kontakt z Pismem Świętym oraz modlitwę i życie sakramentalne. Ważne jest dobre przygotowanie do zawarcia małżeństwa, ale także towarzyszenie młodym małżonkom i rodzinom zwłaszcza w pierwszych latach wspólnego życia. Postulowano zatem organizowanie spotkań modlitewnych oraz grup wsparcia z towarzyszeniem doświadczonych małżonków ${ }^{33}$;

f) Potrzeba jeszcze większego uświadamiania wagi duszpasterstwa małżeńskiego i rodzinnego podczas formacji kapłanów, diakonów, katechetów oraz innych pracowników duszpasterstwa ${ }^{34}$.

Oprócz wymienionych wyżej zasad generalnych, możemy również przytoczyć bardziej szczegółowe kierunki pracy duszpasterskiej, na które zwrócili uwagę ojcowie synodalni.

Po pierwsze, dużej staranności domaga się wypracowanie właściwej formuły przygotowania narzeczonych do małżeństwa, ze zwróceniem uwagi m.in. na wagę czystości jako niezbędnego warunku rozwoju autentycznej miłości międzyosobowej. Należy także wskazywać na organiczny związek, jaki zachodzi pomiędzy sakramentem małżeństwa a wcześniej przyjętymi sakramentami inicjacji chrześcijańskiej. Ważne jest również rozbudzenie świadomości eklezjalnej narzeczonych i zachęcenie ich do aktywnego uczestniczenia w życiu Kościoła ${ }^{35}$.

\footnotetext{
${ }^{31} \mathrm{RS}, \mathrm{nr} 31$.

${ }^{32} \mathrm{RS}, \mathrm{nr} 33$.

${ }^{33}$ Por. RS, nr 40.

${ }^{34}$ Por. RS, nr 37.

${ }^{35}$ Por. RS, nr 39.
} 
W stosunku do młodych małżeństw i rodzin podkreślono wagę wspomnianego już wcześniej towarzyszenia im przez osoby kompetentne i gotowe okazać potrzebna pomoc.

Jeżeli zaś chodzi o osoby żyjące w cywilnym związku małżeńskim lub w konkubinacie, duszpasterze „powinni wyodrębniać elementy, które mogą sprzyjać ewangelizacji oraz wzrastaniu pod względem ludzkim i duchowym. Nowa wrażliwość współczesnego duszpasterstwa polega na wydobywaniu elementów pozytywnych, obecnych w małżeństwach cywilnych, oraz, przy dokonaniu należytych rozróżnień, w konkubinatach. Trzeba, abyśmy w propozycji kościelnej, potwierdzając wszak wyraźnie chrześcijańskie przesłanie, wskazywali także na aspekty konstruktywne w tych sytuacjach, które jeszcze lub już nie są z nim zgodne" ${ }^{\text {36 }}$. Spojrzenie takie służyłoby ukierunkowaniu takich związków na możliwość podążania ku sakramentalnemu małżeństwu. Cierpliwe i delikatne towarzyszenie duchowe mogłoby tu z pewnością więcej zdziałać aniżeli głos surowego potępienia, który oddala.

Podobnie wrażliwa troska duszpasterska powinna dotyczyć ludzi żyjących w innych związkach nieregularnych: przeżywających ból separacji, rozwiedzionych i pozostających samymi, opuszczonych, samotnie wychowujących dzieci, albo tych, którzy po rozwodzie zawarli nowy związek. Wszystkie te przypadki powinny być rozpoznane oddzielnie w duchu miłości pasterskiej i z szacunkiem. Należy dostrzec cierpienie tych ludzi, zwłaszcza tych, którzy zostali porzuceni albo wcześniej maltretowani, co przyczyniło się do przerwania pożycia. Mimo doznanych krzywd, chrześcijańska droga życia zakłada wybaczenie doznanej niesprawiedliwości, co nie jest łatwe, i właśnie temu miałoby dopomóc duszpasterskie pochylenie się nad pokrzywdzonymi osobami.

Osoby rozwiedzione, które nie wstąpiły w powtórny związek małżeński, i często są świadkami wierności, trzeba uświadamiać, że nie mają żadnej przeszkody, aby karmić się Eucharystią. Osoby takie winny znaleźć również potrzebne wsparcie ze strony lokalnej wspólnoty wierzących ${ }^{37}$.

Z kolei rozwiedzeni, którzy wstapili w nowe związki, powinni być zachęcani do udziału w życiu religijnym w takim stopniu, jaki umożliwia im ich sytuacja. Nie są oni wykluczeni z Kościoła. Należy unikać wobec nich języka i postawy sugerujących jakąkolwiek dyskryminację. Nie oznacza to jednak, że ich sytuacja jest tożsama z sytuacją małżonków połączonych więzią sakramentalnego małżeństwa. Trudności obiektywne, wynikające $\mathrm{z}$ istoty znaku sakramentalnego, czynią niemożliwym przyznanie takim małżonkom prawa do przyjmowania komunii świętej. Choć kwestia ta była żywo dyskutowana na synodzie i niektórzy z ojców proponowali nowe rozwiązania w tym względzie (zezwole-

\footnotetext{
${ }^{36} \mathrm{RS}, \mathrm{nr} 41$.

${ }^{37}$ Por. RS, nr 50.
} 
nie po gruntownym rozeznaniu konkretnych przypadków, komunia duchowa) ${ }^{38}$, ostatecznie próby te okazały się mało przekonujące. Ojcowie synodalni zachęcili do pogłębienia refleksji teologicznej w tym względzie. Można bowiem żywić uzasadnione przekonanie, że proponowane zbyt daleko idące ,podejście miłosierne", byłoby jednocześnie zakwestionowaniem wynikającej z nauki Pisma Świętego prawdy znaku sakramentalnego, który wyraża jedyną, wyłączną, wierną miłość Chrystusa do Kościoła. Jest to jedna i ta sama miłość, miłość Chrystusa, która jednoczy człowieka z Bogiem w Eucharystii oraz jednoczy ludzi między sobą przez małżeństwo zawierane w Bogu ${ }^{39}$.

Ojcowie synodu pochylili się także nad sytuacją osób o skłonnościach homoseksualnych. W bardzo zdecydowanych słowach odcięli się od wszelkich prób „rozmywania” dotychczasowego nauczania w tym względzie, bazującego na słowie Bożym i Tradycji. Zastanawiano się, jak otoczyć troską duszpasterską takie osoby, pamiętając jednocześnie, że ,«nie istnieje żadna podstawa do porównywania czy zakładania analogii, nawet dalekiej, między związkami homoseksualnymi a planem Bożym dotyczącym małżeństwa i rodziny». Niemniej mężczyźni i kobiety o skłonnościach homoseksualnych winni być traktowani z szacunkiem i delikatnością. «Powinno się unikać wobec nich jakichkolwiek oznak niesłusznej dyskryminacji» (Kongregacja Nauki Wiary, Uwagi dotyczace projektów legalizacji zwiqzków między osobami homoseksualnymi, 4)" "40. Zwrócono także uwagę, iż zupełnie nie do przyjęcia są jakiekolwiek próby wywierania nacisku przez organizacje międzynarodowe, sugerujące np. możliwość przyznania pomocy finansowej pod warunkiem wprowadzenia ustawodawstwa sprzyjającego legalizacji „małżeństw” osób tej samej płci. Podobny sprzeciw musi budzić wywieranie takich nacisków na duchowieństwo czy związki wyznaniowe, a sami duszpasterze nie powinni im ulegać.

Relatio Synodi odnosi się także do problemu spadku dzietności i zachęca, aby w działaniach duszpasterskich podejmować wyraźną promocję rodzicielstwa z uwzględnieniem wskazań na temat godności przekazywania życia, sformułowanych w encyklice Humanae vitae. Podkreślono niezastapioną rolę rodziców w procesie wychowania dzieci wraz z ich prawem do wyboru treści oraz postaw, jakie pragną przekazać swoim dzieciom ${ }^{41}$.

W zakończeniu omawianego dokumentu ojcowie synodalni wyrazili nadzieję, że podjęta refleksja oraz obrady przyszłego zwyczajnego synodu biskupów,

${ }^{38}$ Por. RS, nr 52-53.

${ }^{39} \mathrm{Na}$ ten temat por. G. Müller, Świadectwo mocy łaski. O nierozerwalności matżeństwa i debacie dotyczqcej dopuszczenia do sakramentów osób rozwiedzionych żyjacych w nowych zwiqzkach, w: Pozostać w prawdzie Chrystusa. Matżeństwo i Komunia w Kościele katolickim, red. R. Dodaro, Poznań 2015, s. 143-159; C. Caffarra, Sakramentalna ontologia a nierozerwalność matżeństwa, w: Pozostać w prawdzie Chrystusa, s. 161-173.

${ }^{40} \mathrm{RS}, \mathrm{nr} 55$.

${ }^{41}$ Por. RS, nr 60. 
poświęconego powołaniu i misji rodziny, pomogą odnaleźć drogi do prawdy i miłosierdzia, co pozwoli z odwagą wiary przyjmować w pokorze i z uczciwością prawdę w miłości.

\section{PODSUMOWANIE}

Obradujący w październiku 2014 roku w Rzymie Nadzwyczajny Synod Biskupów, poświęcony rodzinie, nie był synodem doktrynalnym, lecz duszpasterskim. Taki charakter zapowiadał tytuł obrad, wskazując na problematykę, jaką miał się zająć synod: „Wyzwania duszpasterskie związane z rodziną w kontekście ewangelizacji”. Jego celem nie było wypracowanie nowej doktryny na temat małżeństwa i rodziny, lecz zastanowienie się nad tym, jak pomóc współczesnym małżeństwom i rodzinom, zwłaszcza chrześcijańskim (ale nie tylko), aby w dzisiejszych czasach mogły zachować swoją tożsamość oraz spełniać swoje zadania.

Tak sprecyzowany cel starano się osiagnąć w oparciu najpierw o rozeznanie aktualnej sytuacji, aby w następnym etapie zestawić ją z Bożym zamysłem oraz wiarą Kościoła i spróbować odpowiedzieć na pytanie, co robić, aby w obliczu niewątpliwego kryzysu małżeństwa i rodziny, z nowym entuzjazmem i nowymi metodami nieść światu orędzie Dobrej Nowiny, która ma moc przezwyciężyć każdy kryzys. Być może właśnie taka metodologia obrad - tzn. wyjście od opisu rzeczywistości, a nie od doktryny, wprowadziła pewne zamieszanie w odbiorze referowanych treści. To, że na synodzie kreślono złożoną sytuację małżeństwa i rodziny, nie stroniąc od sytuacji trudnych czy moralnie wattpliwych, nie oznaczało, że samo ich opisywanie oznacza akceptację kontrowersyjnych trendów czy też zgodę na deformację zamysłu Bożego.

Nadzieją dla działań duszpasterskich nie może być jedynie zatrzymanie się na socjologicznym opisie rzeczywistości, by na jego podstawie formułować wnioski praktyczne, ale potrzebne jest zwrócenie się do biblijnego przesłania na temat małżeństwa i rodziny, jakie Kościół od wieków strzeże w depozycie apostolskiej wiary. Jakakolwiek próba zmiany treści tego depozytu, motywowana nawet szlachetnymi pobudkami, nie może być usprawiedliwiona. Objawionej prawdy na temat małżeństwa i rodziny, odkrywanej po części również światłem naturalnego rozumu, nie można zmieniać, powołując się na postępowanie ludzi mających trudności z jej przeżywaniem lub pod wpływem nacisków tych, którzy jej nie przyjmują. Gdyby przyjąć taką optykę ,pozornego miłosierdzia”, to już pierwotny Kościół musiałby zrezygnować z nauczania Chrystusa o małżeństwie lub czystości, gdyż w pogańskim świecie, z którym się stykał, normy te masowo nie były respektowane. Tymczasem właśnie zdecydowana inność myślenia i stylu życia zaczynały pociągać, gdyż promieniowała z nich „Ewangelia życia”. Kto przyjął tę Dobrą Nowinę, otrzymywał od Boga siłę, aby sprostać wymaganiom 
moralnym i współtworzyć nową cywilizację, alternatywną do umierającego antyku.

Podobnie jest i dziś. Nie ma niczego niestosownego w opisie złożonej sytuacji współczesnej rodziny, którego częścią składową, obok zdrowych relacji, są sytuacje trudne czy wręcz dramatyczne. Faktycznie, istnieją rozwody, powtórne małżeństwa, wolne związki, związki partnerskie. Jednakże te ludzkie skomplikowane i trudne sytuacje nie mogą być jedynym motywem, w świetle którego Kościół chce im wychodzić naprzeciw. On chce im wyjść naprzeciw, aby im pomóc, a nie pomoże powołując się na ich sytuację, lecz przynosząc im zbawczą miłość Boga. A Bóg nie zostawia nas w naszej sytuacji, lecz podnosi nas i daje moc nowego życia. To jest centralne przesłanie Ewangelii miłosierdzia.

Ludzie szukają ratunku w różnego rodzaju związkach i w tym pragnieniu można odczytać ślady pierwszego stopnia odwiecznego zamysłu Bożego, objawionego w Księdze Rodzaju: „nie jest dobrze, aby człowiek był sam” (Rdz 2,18). Duszpasterstwo powinno tak towarzyszyć ludziom dzisiejszych czasów, aby odkrywali kolejne stopnie Bożego zamysłu objawionego w Biblii. Nikt nie zna lepiej człowieka niż jego Stwórca. Jeśli chcemy pomóc małżeństwu i rodzinie, nie powinniśmy robić tego wbrew Bożej mądrości i miłości. Mogłoby się czasem okazać, że powtarzamy rajski błąd słuchania innego głosu, głosu przeciwnika Bożego, Szatana, któremu wciąż zależy, aby udaremnić zamysł Boży.

\section{SUMMARY}

The Extraordinary Synod of Bishops at the Vatican in 2014 was dedicated to the pastoral care of the family. From the very beginning of the synod, and even before it had started, it was accompanied with a large dose of emotion and media commentaries. Some of the reports have begun to create a specific atmosphere around the synod, seeing in it a breakthrough which is able to change the existing discipline, and perhaps, even the doctrine of the Church on marriage and family.

This article indicates expectations of the world directed at the Church, which were spoken in many mass-media. It reminds the discussion which was rolling around the synod and finally reveals the official position of the synod specified in the final document Relatio Synodi.

\section{Keywords}

Extraordinary Synod of Bishops, family, divorce, remarriage, discipline of sacraments

\section{BIBLIOGRAFIA}

Caffarra C., Sakramentalna ontologia a nierozerwalność matżeństwa, w: Pozostać w prawdzie Chrystusa. Matżeństwo i Komunia w Kościele katolickim, red. R. Dodaro, Poznań 2015, s. 161-173. 
Dudek A.J., Giacomo Galeazzi: za Franciszka rewolucja formy staje się rewolucją treści. Synod jest tego dowodem, http://natemat.pl/120293, giacomo-galeazzi-za-franciszkarewolucja-formy-staje-sie-rewolucja-tresci-synod-jest-tego-dowodem [dostęp: 3.11.2014].

Grocholewski Z., Synod Biskupów w życiu Kościoła, http://www.opoka.org.pl/biblioteka/ W/WR/inne/grocholewski_synodbp2005.html\# [dostęp: 3.11.2014].

Jagodziński S., Müller G., Niektórzy biskupi dali się oślepić, http://www.naszdziennik.pl/ wiara-kosciol-na-swiecie/106377,niektorzy-biskupi-dali-sie-oslepic.html [dostęp: 3.11. 2014].

Kodeks prawa kanonicznego, przekład polski zatwierdzony przez Konferencję Episkopatu, Poznań 1984.

Müller G., Świadectwo mocy taski. O nierozerwalności matżeństwa i debacie dotyczqcej dopuszczenia do sakramentów osób rozwiedzionych żyjących w nowych zwiazkach, w: Pozostać w prawdzie Chrystusa. Matżeństwo i Komunia w Kościele katolickim, red. R. Dodaro, Poznań 2015, s. 143-159.

Papież do ojców synodalnych: mówcie szczerze i pokornie stuchajcie, http://ekai.pl/wydarzenia/temat_dnia/x82577/papiez-do-ojcow-synodalnych-mowcie-szczerze-i-pokornie-sluchajcie/ [dostęp: 11.10.2014].

Relatio Synodi III Nadzwyczajnego Zgromadzenia Ogólnego (5-19 października 2014), http://archidiecezja.warszawa.pl/ksieza/dokumenty/stolica-apostolska/relatio-synodi/ [dostęp: 18.11.2015].

Sawicki K., Synod Biskupów zakończony. Kontrowersyjne paragrafy odrzucone, ale dyskusja trwa, http://tygodnik.onet.pl/wwwylacznie/synod-biskupow-zakonczony-kontro wersyjne-paragrafy-odrzucone-ale-dyskusja-trwa/j2q14 [dostęp: 12.11.2014].

Seks, gender i homo, czyli co slychać na Synodzie, http://tygodnik.onet.pl/wwwylacznie/ seks-gender-i-homo-czyli-co-slychac-na-synodzie/1xnjg [dostęp: 3.11.2014].

Synod - duszpasterskie trzęsienie ziemi, http://ekai.pl/wydarzenia/temat_dnia/x82880/sy nod-duszpasterskie-trzesienie-ziemi/?page=4, [dostęp: 12.11.2014].

Synod o rodzinie - tydzień pierwszy, http://ekai.pl/wydarzenia/temat_dnia/x82770/synodo-rodzinie-tydzien-pierwszy/?page $=5$ [dostęp: 12.10.2014].

Maciej Olczyk - ks. dr hab. jest adiunktem Zakładu Teologii Moralnej, Duchowości i Katolickiej Nauki Społecznej na Wydziale Teologicznym Uniwersytetu im. Adama Mickiewicza w Poznaniu. Pracuje naukowo i dydaktycznie, prowadząc badania w obszarze etyki teologicznej. Autor publikacji z zakresu teologii moralnej fundamentalnej, antropologii teologicznej, teologii małżeństwa i rodziny, bioetyki oraz etyki seksualnej. W swoich pracach nawiązuje do aktualnych problemów społecznych, dylematów etycznych i zachodzących przemian obyczajowych. 